\title{
Darba līguma uzteikums darbiniekam - arodbiedrības biedram
}

\author{
Agnese Reine \\ Rìgas Stradiṇa universitāte, Juridiskā fakultāte, Latvija \\ agnesereine@inbox.lv
}

\section{Kopsavilkums}

Latvijas Republikas Satversmes 102. pantā noteikts, ka ikvienam ir tiesības apvienoties biedrībās, politiskās partijās un citās sabiedriskās organizācijās [3]. Darba tiesiskās attiecības ir cieši saistītas ar biedrošanās brīvību. Biedrošanās brīvības jēdziens ietver arī darbinieku tiesības brīvi apvienoties arodbiedrībās, veidojot sasaisti ar darba tiesiskajām attiecībām.

Darba likuma 110. panta pirmajā daḷā noteikts, ka darba devējam ir aizliegts uzteikt darba līgumu darbiniekam - arodbiedrības biedram - bez attiecīgās arodbiedrības iepriekšējas piekrišanas [2]. Ar Darba likuma 101. panta sesto dalı darba devējam pirms darba līguma uzteikšanas tiek uzlikts pienākums noskaidrot, vai darbinieks ir darbinieku arodbiedrības biedrs [2]. Taču normatīvajā regulējumā nav paredzēta darba devēja rīcība situācijā, ja darbinieks ir vairāku arodbiedrību biedrs. Regulējuma nepilnību dēl uzteikuma izsniegšanas brīdì darba devējam rodas problēmsituācija. Turklāt iegūt informāciju par to, vai darbinieks ir vienas vai vairāku arodbiedrību biedrs, darba devējs var tikai no paša darbinieka, tādējādi jau preventīvi darba devējs paziṇo darbiniekam par plānoto uzteikumu. Šãdi apstākḷi darbiniekam dod iespēju nekavējoties iestāties arodbiedrībā, lai radītu grūtības darba devējam izsniegt uzteikumu.

Atslēgvārdi: darbinieks, darba devējs, arodbiedrība, Darba likums.

\section{levads}

Ikviena cilvēka pamattiesības ietver biedrošanās brīvību, kas iekḷauj arī tiesības dibināt biedrības un iestāties tajās. Daudzu gadu gaitā biedrošanās brīvība tika strauji attīstīta, un mūsdienās arodbiedrības ieṇem ḷoti būtisku lomu darba devēju un darbinieku savstarpējās attiecībās. Šobrīd Lat vijas Brīvo arodbiedrību savienība apvieno 20 dalīborganizācijas, kurās kopā ir ap 100000 biedru [12]. Šãdi statistiskie dati apliecina šà pētỉjuma tēmas aktualitāti. 
Problēmsituācijas rodas brīdī, kad darba devējs vēlas izsniegt uzteikumu darbiniekam, kurš ir vienas vai vairāku arodbiedrību biedrs. Darba likuma 110. panta pirmajā daḷā noteikts, ka darba devējam aizliegts uzteikt darba līgumu darbiniekam - arodbiedrības biedram - bez attiecīgās arodbiedrības iepriekšējas piekrišanas [2]. Šobrīd spēkā esošais tiesiskais regulējums ir nepilnīgs un nenosaka darba devēja rīcību situācijā, ja darbinieks ir vairāku arodbiedrību biedrs.

Šã pētījuma mērḳis ir noskaidrot arodbiedrību ietekmi uz darba devēju un darbinieku tiesiskajām attiecībām darba uzteikuma gadījumā, kāa arī ieteikt tiesiskā regulējuma uzlabojumus, lai novērstu problēmsituācijas šajā jomā.

Darbā tika analizēta pieejamā literatūra, normatīvie akti un tiesu prakse. Tika izmantota gramatiskā un sistēmiskā tiesību normu interpretācijas metode, ar kuru ir skaidrota galvenokārt Darba likuma un Arodbiedrību likuma vārdu izpratne no gramatiskā / valodnieciskā aspekta, savukārt ar sistēmisko tiesību normu interpretācijas metodi meklētas kopsakarības Satversmes, Darba likuma un Arodbiedrību likuma normās. Tika izmantota arī logiiskā, vispārēji zinātniskā pētniecības metode, pētot logisko saikni starp likuma normu piemērošanu un tulkošanu.

\section{Biedrošanās brīvība un arodbiedrība: jēdzienu skaidrojums}

Lai varētu izanalizēt arodbiedrību ietekmi uz darbinieku un darba devēju savstarpējām tiesiskajām attiecībām uzteikuma gadījumā, sākotnēji ir jāsniedz biedrošanās brīvības un darba tiesisko attiecību būtības skaidrojumi.

Vispirms jānoskaidro jēdziena "biedrošanās brīvība" būtība.

Latvijas Brīvo arodbiedrību savienības interneta vietnē ir pieejams šāds jēdziena "arodbiedrība" skaidrojums: "Arodbiedrība ir neatkarīga nevalstiskā organizācija, kas pārstāv un aizstāv savu biedru darba un citas sociālās un ekonomiskās tiesības un intereses saskañā ar Arodbiedrību likumu, citiem spēkā esošiem likumiem un Latvijas Republikas arodbiedrību statūtiem." [9].

Latvijas Zinātṇu akadēmijas akadēmiskajā terminu datubāzē pieejams šāds skaidrojums: "Arodbiedrība ir neatkarīga sabiedriska organizācija, kas pauž, pārstāv un aizstāv savu biedru darba un citas sociālās un ekonomiskās tiesības un intereses, ievērojot principus un normas, kas noteiktas Vispārējā cilvēktiesību deklarācijā un citos starptautiskajos paktos un konvencijās. Arodbiedrības savā darbībā ir neatkarīgas no valsts varas un pārvaldes institūcijām, citām organizācijām un ir savstarpēji līdztiesīgas" [8].

Izanalizējot šos arodbiedrības jēdziena skaidrojumus, var secināt, ka visos skaidrojumos kopīgais ir arodbiedrības pārstāvība un savu biedru interešu aizstāvība. Cilvēki apvienojas, lai sasniegtu kopīgus mērḳus, un būtiski ir tas, ka arodbiedrības ir neatkarīgas un to tiesiskais statuss ir noteikts - nevalstiska organizācija. Šie ir galvenie atslēgvārdi arodbiedrības jēdziena skaidrojumos, un tie arī atklāj jēdziena būtību. 
Agnese Reine. Darba līguma uzteikums darbiniekam - arodbiedrības biedram

\section{Tiesisko attiecību regulējums}

Starptautiskā pakta par pilsoniskajām un politiskajām tiesībām 22. panta pirmajā un otrajā daḷa noteikts, ka katram ir tiesības uz biedrošanās brīvību ar citiem, ieskaitot tiesības dibināt arodbiedrības un iestāties tajās, lai aizsargātu savas intereses [5]. Šo tiesību izmantošanā nav nekādu ierobežojumu, izṇemot tos, kas paredzēti likumā un kas nepieciešami demokrātiskā sabiedrībā valsts vai sabiedriskās drošības un sabiedriskās kārtības interesēs, iedzīvotāju veselības vai citu personu tiesību un brīvību aizsardzībai.

Izpētot šos skaidrojumus, kā arī starptautiskos normatīvos aktus un Latvijas Republikas likumus, redzams, ka šobrīd pamattiesību un rīcības brīvības regulējums, kas attiecināms arī uz biedrošanās brīvību, ir plašs un arī loti precīzs. Par arodbiedrībām, biedrošanās brīvību, iestāšanos un tiesībām veidot arodbiedrības pieejams ḷoti konkrēts regulējums. Uz Latvijas Republiku attiecas ne tikai šeit izdotie tiesību akti, bet arī starptautiskie normatīvie dokumenti, kas ir vēl viens garants tam, ka šis regulējums ir loti precīzs un nepārprotams.

Darba tiesiskajās attiecībās biedrošanās brīiība tiek realizēta ar darbinieku pārstāvju palīdzību. Darba tiesiskās attiecības regulē Latvijas Republikas Satversme, Latvijai saistošās starptautiskās tiesību normas, Darba likums un citi normatīvie akti, kā arī darba koplīgums un darba kārtības noteikumi [2].

Lai izprastu darba tiesisko attiecību būtību, jāiepazīstas ar dažādiem literatūrā piedāvātajiem jēdziena "darba tiesiskās attiecības" skaidrojumiem.

Darba tiesiskās attiecības ir darbinieka un darba devēja tiesiskās attiecības, kurās darbinieks uzṇemas veikt noteiktu darbu, pakḷaujoties noteiktai darba kārtībai un darba devēja rīkojumiem, bet darba devējs - maksāt nolīgto darba samaksu un nodrošināt taisnīgus, drošus un veselībai nekaitīgus darba apstākḷus [4]. Darba tiesiskās attiecības ir darba tiesību kā patstāvīgas tiesību nozares priekšmets, un šīs tiesiskās attiecības regulē darba tiesību normas. Darba likumā ietvertās tiesību normas l̦auj secināt, ka darba tiesiskās attiecības ir tiesiskās attiecības starp darba devēju un darbinieku, tās tiek dibinātas uz darba līguma pamata sakarā ar atalgota darba veikšanu, ja tā veikšanas laikā darbinieks ir personiski paḳ̣auts darba devējam [13, 10]. Savukārt "Juridisko terminu vārdnīcā" sniegts skaidrojums, ka darbtiesiskās attiecības ir juridiskās attiecības starp darbinieku un darba devēju, kas radušās uz darba līguma pamata [11, 56].

Pēc jēdziena "darba tiesiskās attiecības" skaidrojumu izpētes var secināt, ka darba tiesiskās attiecības ir darbinieka un darba devēja savstarpējās darba attiecības, kas dibinātas uz darba līguma pamata un kuras regulē speciāli normatīvie akti, kuros noteiktas gan abu pušu tiesības un pienākumi, gan darba samaksa, darba kārtība un citas funkcijas.

Darbinieki savu sociālo, ekonomisko un profesionālo tiesību un interešu aizstāvību īsteno tieši vai ar darbinieku pārstāvju starpniecību. Darbinieku pārstāvji (Darba likuma izpratnē) ir arodbiedrības vai kvalificētie pārstāvji un darbinieku pilnvarotie pārstāvji [2]. 
Šajā darbā (atbilstoši pētāmajam jautājumam) tiek analizēti tikai kvalificētie darbinieku pārstāvji vai arodbiedrības. Par augstākas organizācijas formu un pastāvīgāku darbinieku pārstāvi tiek uzskatīta arodbiedrība. Arodbiedrība ir neatkarīga sabiedriska organizācija, kas pauž, pārstāv un aizstāv savu biedru darba un citas sociālās un ekonomiskās tiesības un intereses $[13,10]$. Arodbiedrību mērḳis ir pievērst uzmanību darbinieku vajadzībām, panākt vinu ienākumu nepārtrauktu pieaugumu vai vismaz to stabilitāti, darba tiesību īstenošanu un tādu sociālo garantiju nodrošināšanu, kas veicina personības brīvību un vispusīgu attīstību. Arodbiedrībām ir liela nozīme darbinieku tiesību aizsardzībā, jo tās apvieno nozaru un profesionālās arodbiedrības kopējo darba, ekonomisko un sociālo tiesību aizstāvībai; īsteno sociālo dialogu ar valdību un darba devēju organizācijām; pārstāv darbinieku intereses valsts un pārvaldes institūcijās un tiesā; veic likumu, citu tiesību aktu projektu ekspertīzi un izstrādā priekšlikumus izmaiṇām; organizē savu biedru izglītošanu; piedalās starptautiskajā arodbiedrību kustībā un veicina citas darbinieku tiesības veicinošas darbïbas [9].

Arī kvalificētie darbinieku pārstāvji var nodrošināt augsta līmeņa biedru pārstāvību, kā arì izmantot savas tiesības piedalīties likumprojektu izstrādē, kas var nodrošināt jau preventīvu, biedriem svarīgu jautājumu iekḷaušanu likumprojektos. Taču viena no galvenajām garantijām, ko nodrošina iestāšanās arodbiedrībā, ir darbinieka aizsardzība, jo saskañā ar Darba likuma 110. pantu darba devējam aizliegts uzteikt darba līgumu darbiniekam - arodbiedrības biedram - bez attiecīgās arodbiedrības iepriekšējas piekrišanas, izṇemot gadijjumus, kas noteikti Darba likuma 47. panta pirmajā daḷā un 101. panta pirmās dal̦as 4., 8. un 10. punktā [2].

Lai varētu izprast arodbiedrību ietekmi uz darba devēja un darbinieka savstarpējām tiesiskajām attiecībām situācijā, kad darba devējs vēlas izsniegt uzteikumu darbiniekam, kurš ir arodbiedrības biedrs, ir jāanalizē normatīvais regulējums.

\section{Problēmas ar darba uzteikumu arodbiedrības biedram}

Atbilstoši Darba likuma 101. panta sestajai daḷai pirms darba līguma uzteikšanas darba devējam ir pienākums noskaidrot, vai darbinieks ir arodbiedrības biedrs. Šã likuma 110. panta pirmajā daḷā noteikts, ka darba devējam ir aizliegts uzteikt darba līgumu darbiniekam - arodbiedrības biedram - bez attiecīgās arodbiedrības iepriekšējas piekrišanas [2]. Tiesību normā imperatīvā formā ir noteikti priekšraksti, kas darba devējam jāievēro, uzteicot darba līgumu darbiniekam, kas ir arodbiedrības biedrs.

Analizējot tiesu praksi, var secināt, ka problēmsituācijas rodas brīdī, kad darbinieks ir vairāku arodbiedrību biedrs. Šobrīd spēkā esošais normatīvais regulējums nenosaka darba devēja rīcību šādā situācijā. Vai darba devējam būtu jāprasa aț̣auja uzteikuma izsniegšanai visām arodbiedrībām vai tikai vienai?

Analizējot vairākus tiesas spriedumus, redzams, ka darbinieku pārstāvju loma in ḷti liela un noteicoša. Izpētot Augstākās tiesas Senāta spriedumu lietā Nr. SKC-1144/2013 [6], 
var secināt, ka brīdī, kad darba devējs izsniedz uzteikumu darbiniekam, kurš ir arodbiedrības biedrs, turpmākā situācija var kḷūt sarežgiìta ne tikai tāpēc, ka arodbiedrība var nedot atḷauju uzteikuma izsniegšanai, bet gan lielākoties iespējamo tiesvedību dēḷ. Lai gan darba devējs izpilda likumā noteiktos nosacījumus, darbinieks vienalga var censties ar tiesas palīdzību panākt savu atjaunošanu darbā, pieprasìt kompensācijas u. tml., izmantojot šādus argumentus: atḷaujas pieprasī̌̌anas un atbildes sniegšanas laiku, kas gan ir konkrēti noteikts likumā; arodbiedrību skaitu un to, ka darba devējs aț̣auju nav prasījis visām arodbiedrībām, kurās darbinieks iestājies. Pēc šì konkrētā Senāta sprieduma lietā Nr. SKC-1144/2013 [6] var secināt, ka arī darba devējs tiek aizstāvēts un aizsargāts un situācijā, kad jāizsniedz darbiniekam uzteikums, darba devējam ir tiesības to izsniegt, izpildot likumā noteiktās normas. Nav nepieciešams pieprasìt aț̣auju no visām arodbiedrībām, kurās darbinieks iestājies. Jāatceras, ka visas arodbiedrības pauž vienotu viedokli. Šeit nevar būt savstarpēja konkurence. Taču būtu nepieciešams šādu nosacījumu ietvert arī normatīvajos aktos, jo tiesu lēmumi līdzīgās lietās atškiras. Izpētot Augstākās tiesas spriedumu lietā Nr. SKC-764/2012 [7], redzams, ka darba devējs var kḷūt "situācijas ḳilnieks". Šis tiesas spriedums ir pretējs iepriekšminētajam. Šajā spriedumā tiesa lēma par labu darbiniekam, atjaunoja viṇu darbā, un darba devēja kasācijas sūdzība tika noraidita.

Lai gan Augstākās tiesas Senāts ir pateicis, ka darba devējam uzteikuma izsniegšanas gadījumā jāprasa aț̣auja tikai vienai arodbiedrībai, aplūkojot šobrīd spēkā esošo normatīvo regulējumu, rodas citi problemātiski aspekti.

Likuma "Par arodbiedrībām" 2. pantā [4] bija noteikts, ka arodbiedrība var apvienoties teritoriālajās vai nozaru savienībās. Taču līdz ar jaunā Arodbiedrību likuma [1] stāšanos spēkā 2014. gada 1. novembrī šì norma tika atcelta, apgrūtinot darba devējam iespējas atrast un sazināties ar attiecīgajām arodbiedrībām. Šāda nepilnība regulējumā veicina situācijas, ka rodas šaubas par arodbiedrību kompetenci izvērtēt un pieṇemt lēmumu par uzteikuma izsniegšanu darbiniekam, kas ir arodbiedrības biedrs. Nemot vērā, ka normatīvajā regulējumā nav nosacījuma veidot arodbiedrības pēc nozaru specializācijas un ikvienam ir tiesības brīvi apvienoties un iestāties arodbiedrībās, rodas paradoksāla situācija, jo, piemēram, lēmumu par uzteikuma izsniegšanu ārstam ir jāpieṇem celtnieku arodbiedrībai. Vai šajā gadījumā arodbiedrības pien,emtais lēmums par uzteikuma izsniegšanu arodbiedrības biedram būs kompetents?

N̦emot vērā minēto, var uzskatìt, ka nepieciešams veikt grozījumus Arodbiedrību likumā, iekḷaujot tajā nosacījumu, ka arodbiedrībās var apvienoties pēc nozaru specializācijas. Šobrīd Arodbiedrību likumā nav noteikts regulējums, kā darba devējam jārīkojas, ja darbinieks ir vairāku arodbiedrību biedrs. Tādēl jāveic grozijumi Arodbiedrību likumā un jānoteic: lai izsniegtu uzteikumu, darba devējam ir jāprasa atḷauja tikai vienai arodbiedrībai, izvēloties to pēc nozaru specializācijas. Kompetentākais viedoklis būs tai arodbiedrībai, kura pārstāv konkrētās nozares arodbiedrības biedrus. 
Agnese Reine. Darba līguma uzteikums darbiniekam - arodbiedrības biedram

\section{Secinājumi}

Tas, ka darba devējam pirms uzteikuma izsniegšanas darbiniekam ir jānoskaidro, vai darbinieks ir kādas arodbiedrības biedrs, liek secināt, ka normatìvais regulējums rada problēmsituāciju. Vienīgais veids, kā darba devējs var šādu informāciju iegūt, ir pajautāt to darbiniekam. Bet šāda rīcība rada situāciju, ka darba devējam jau preventīvi jāpazinno darbiniekam, ka tiek plānots izsniegt uzteikumu. Šo apstākli var izmantot darbinieki un nekavējoties iestāties arodbiedrībā, lai apgrūtinātu darba devēja iespējas izsniegt uzteikumu. Praksē ir zināmi gadījumi, ka dažreiz darbinieki izmanto privātās attiecības un noformē iestāšanos arodbiedrībā ar atpakaļejošu datumu, lai darba devējs nevarētu izsniegt uzteikumu.

Lai šādas situācijas novērstu, vajadzētu izanalizēt, izstrādāt un ieviest speciālu sistēmu, kurā tiktu reǵistrēta informācija par iestāšanos arodbiedrībā. Dati sistēmā būtu jāregistrē, piemēram, piecu dienu laikā kopš iestāšanās arodbiedrībā. Izveidotā sistēma, protams, nedrīkst būt publiski pieejama, t. sk. nedrīkst būt brīvi pieejama darba devējam. Apkopotā informācija par dalību arodbiedrībās varētu tikt izmantota arī diskriminējoši, tādēl kārtībai jābūt šādai: darba devējs brīdī, kad vēlas izsniegt darbiniekam uzteikumu, vēršas ar pieprasijumu pie datu operatora, kur saṇem informāciju par to, vai konkrētais darbinieks ir kādas arodbiedrības biedrs. Protams, ir nepieciešama detalizēta analīze, lai varētu pateikt, kura iestāde varētu apkopot un apstrādāt šādus datus, taču šādas sistēmas izveide novērstu situāciju, ka darba devējam savā ziṇā jau iepriekš jāpazinno darbiniekam par plānoto uzteikuma izsniegšanu tikai tādēl, lai noskaidrotu, vai darbinieks ir kādas arodbiedrības biedrs.

Pētỉjuma gaitā radās šādi secinājumi:

1) biedrošanās brīvība ir ikviena cilvēka pamattiesības, kuras noteiktas Latvijas Republikas Satversmē;

2) arodbiedrības ir biedrības, un kvalificētie darbinieku pārstāvji, kas pārstāv un aizstāv savu biedru intereses, apvienojas, lai sasniegtu kopīgus mērḳus;

3) uzteikuma izsniegšanu darbiniekam, kas ir arodbiedrības biedrs, regulē Darba likums, taču regulējums ir nepilnīgs un rada problēmas darba devējam;

4) problēmsituācija veidojas gadījumā, kad darbinieks ir vairāku arodbiedrību biedrs, jo tiesiskajā regulējumā nav noteikta darba devēja rīcība šādā situācijā;

5) tiesu prakse par uzteikuma problēmu darbiniekam, kas ir arodbiedrības biedrs, ir plaša;

6) no jaunā Arodbiedrību likuma ir izslēgta norma par arodbiedrību apvienošanos atbilstīgi nozarei;

7) lai novērstu preventīvu darbinieka informēšanu par plānotu uzteikuma izsniegšanu un iespēju darbiniekam nekavējoties iestāties arodbiedrībā, jāveic pētỉjums par programmas izstrādi un datubāzes izveidi, kurā tiktu registrēti dati par darbinieku piederību vienai vai vairākām arodbiedrībām. 
Izanalizējot problēmsituācijas, kas var rasties, izsniedzot uzteikumu darbiniekam arodbiedrības biedram, var secināt, ka šobrīd spēkā esošais regulējums var radīt problēmsituācijas gan darbiniekam, gan arī darba devējam. Regulējuma trūkums vai tā nepilnības veicina situācijas, ka darbiniekam var tikt nepamatoti izsniegts darba līguma uzteikums vai arī darba devējs kḷūst par "situācijas ḳilnieku", jo nevar izsniegt pamatotu uzteikumu darbiniekam arodbiedrības kompetences trūkuma dẹl. Ieviešot piedāvātos grozījumus un papildinājumus normatīvajos aktos, tiktu uzlabotas darba devēju, darbinieku un arodbiedrību trīspusējās attiecības, novērstas problēmsituācijas uzteikuma izsniegšanā, kā arī samazināts tiesu prakses gadījumu skaits.

\section{Notice of Termination of Legal Relationship at Work for the Member of the Trade Union}

\section{Abstract}

According to the Constitution of the Republic of Latvia is provided in Article 106, that everyone has the right to freely select employment and job according to its own abilities and skills. Legal relationship at work is closely related to freedom of association. The concept of freedom of association includes employees' rights to freely form trade unions, which is also a link with the employment relationship. The first part, Article 110 of Labour law determines, that the employer does not have right to terminate the employment contract with a member of trade union without a permission of that trade union. But the 6th part, Article 101 determines that the employer must clarify if the employee is the member of a trade union before terminating the employment contract.

However, the regulatory framework does not provide employer action in situations when employee is a member of several trade unions. Employer can find out is the employee member in one or more trade unions, only from the employee, accordingly employer preventive notify employee, that he wants to give him notice of termination of legal relationship. This situation gives an opportunity to employee to join trade union immediately, to make difficulties for employer.

Keywords: employee, employer, trade union, Labour law.

\section{Avoti un literatūra}

\section{Tiesību akti}

1. Arodbiedrību likums: Latvijas Republikas likums: pieṇemts 06.03.2014. un stājas spēkā 01.11.2014. Latvijas Vëstnesis. 60 (5120), 25.03.2014.

2. Darba likums: Latvijas Republikas likums: pieņemts 20.06.2001. un stājas spēkā 01.06.2002. Latvijas Vēstnesis. 105(2492), 06.07.2001.

3. Latvijas Republikas Satversme: LV likums: pieṇemts 15.02.1922. un stājas spēkā 07.11.1922. Latvijas Vēstnesis. 43, 01.07.1993. 
Agnese Reine. Darba līguma uzteikums darbiniekam - arodbiedrības biedram

4. Likums "Par arodbiedrībām”: Latvijas Republikas likums: pieṇemts 13.12.1990. un zaudējis spēku 01.11.2014. Ziṇotājs. 3/4, 31.01.1991.

5. Starptautiskais pakts par pilsoṇu un politiskajām tiesībām: starptautisks dokuments. Apvienoto Nāciju Organizācija. Latvijas Vēstnesis. 61(2826), 23.04.2003.

\section{Tiesu prakse}

6. Augstākās tiesas Senāta 2013. gada 26. aprīḷa spriedums lietā Nr. SKC-1144/2013.

7. Latvijas Republikas Augstākās tiesas Senāta 2012. gada 6. jūnija spriedums lietā Nr. SKC-764/2012.

\section{Literatūra}

8. Arodbiedrība. Akadēmiskā terminu datubāze Akadterm. Iegūts no: http://termini.lza.lv/term. php?term=arodbiedr\%C4\%ABba\&list=arodbiedr\%C4\%ABba\&lang=LV [sk. 20.04.2017.].

9. Arodbiedrības. Latvijas Brīvo arodbiedrību savienība. Iegūts no: http://www.lbas.lv/about/ trade-union [sk. 20.04.2017.].

10. Darba attiecības un sociālais dialogs. Labklājības ministrija. Iegūts no: https://www.lm.gov.lv/ text/4.09 [sk. 21.04.2017.].

11. Juridisko terminu vārdnīca. V. Dubure, A. Fogels, I. Fridrihsons u. c. Rīga: Nordik, 1998.

12. Latvijas Brīvo arodbiedrību savienība. Iegūts no: http://www.lbas.lv/about [sk. 20.04.2017.].

13. Slaidin,a, V., Skultāne, I. Darba tiesības. Rīga: Apgāds Zvaigzne ABC, 2011. 